\title{
When the Spirit Leaves: Childhood Death, Grieving, and Bereavement in Islam
}

\author{
KAMYAR HEDAYAT, M.D.
}

\begin{abstract}
The death of a child has a profound and often long-lasting impact on families. The parent's relationship and their ability to bond with and take care of surviving children may be affected. It is important for healthcare workers to understand the dynamics associated with bereavement, especially when the family comes from a non-Western culture. Islam is one of the three most populous religions along with Christianity and Hinduism and the fastest growing religion in the United States but remains largely misunderstood. This paper seeks to explain what Islam is, who is a Muslim, where they live, and what they believe and practice. It also explains how Islamic beliefs contextualize the meaning of life and death for Muslims and how they are exhorted to grieve upon a child's death. Reading this paper will enable those who care for Muslim families to better attend to the social and emotional needs of Muslim parents and siblings after such a tragic event.
\end{abstract}

\section{INTRODUCTION}

We have decreed Death to be your common lot . . . (56:60) $)^{1}$

E VERY YEAR in the United States approximately 50,000 children die. ${ }^{2}$ One half die in infancy, the remaining in childhood or as teenagers. The five most frequent causes of death in 2004 were accidental trauma $(20 \%)$, congenital anomalies $(10 \%)$, prematurity $(8 \%)$, homicide $(5 \%)$, and neoplasms (4\%), accounting for nearly half of all pediatric deaths. The vast majority of pediatric deaths occur in hospitals, including, in addition to those named above, oncology-related illnesses, sepsis, and acute respiratory distress syndrome. A plurality of these deaths occurs in an intensive care unit, namely $40 \%$ of infants and approximately $25 \%$ of children. ${ }^{3}$
Little objective study of Muslim attitudes toward death has been done in Western languages, and even fewer regarding the death of infants. One study of Arab women whose children died in Swedish neonatal intensive care units (NICUs) demonstrated how "standard" acts of consolation such as pictures and footprints or viewing the deceased child actually offended the grieving mothers and caused distress. ${ }^{4}$ Eastern cultures, regardless of the religious tradition, tend to allow for more emotionality. ${ }^{5}$ A higher degree of religiosity may lead to less anxiety during periods of grief among Muslims as in other faith communities. ${ }^{6}$ On the other hand, sudden or explained death may lead to a high degree of posttraumatic stress disorder and grief. ${ }^{7}$ This paper examines Islamic proscriptions on death, bereavement, and mourning rituals. A case study based on the Prophet Mohammad's reaction to the death of

Pediatric Critical Care, Integrative Medicine, Sutton Children's Hospital, Shreveport, Louisiana. 
his infant son is presented to illustrate Islamic mourning rituals.

\section{EPIDEMIOLOGY OF DEATH AMONG MUSLIM CHILDREN}

Developing nations tend to have higher childhood mortality rates than industrialized nations. ${ }^{8}$ Muslim children die of various causes depending on the country in which they live. Childhood mortality rate and exposure to the death of a prior child varies as well. Violent deaths are frequent in war-stricken areas such as Palestine ${ }^{9}$ and Iraq. ${ }^{10}$ In countries such as Somalia, with little or no health care infrastructure, respiratory and diarrheal deaths predominate. ${ }^{11}$ Some countries have little violent or illness-related deaths as a result of advanced health care systems but high traffic-related deaths for children, such as the United Arab Emirates. ${ }^{12}$ Therefore, there is no uniform experience with childhood deaths among immigrant Muslims.

Black children in the United States have double the mortality of white children. They are also twice as likely to die a violent death resulting from gang-related violence. ${ }^{13}$ It is estimated that approximately one third of all Muslims in the United States are black, mainly inner city dwellers. At present, no figures are available to differentiate between the mortality rate of black Muslim and black Christian children in the United States, or between Muslim and non-Muslim immigrants. However, most immigrant groups have lower incidents of violent death in children under 14 compared to native children. This finding has been attributed to more traditional parenting models and emphasis on family values among immigrants. ${ }^{14}$

\section{ISLAM}

Islam is a monotheistic religion established in $610 \mathrm{AD}$ by the Prophet Muhammad. Islam is an Abrahamic faith, like Judaism and Christianity, through Abraham's first son, Ishmael, the forefather of the Prophet Muhammad. The tenets and practices of Islam are simple and easy to follow, contributing to its spread across a wide geographic area (Table 1). There is no "typical" Muslim: 40\% are Asian from India, Pakistan, Afghanistan, Indonesia, Malaysia, China, and the
Philippines, etc.; $30 \%$ are from sub-Saharan Africa; 20\% are from the Middle East (including non-Arab Iran and Turkey); 3\% are native to Europe; and $1 \%$ are native to the Americas (the latter two include converts and immigrants). ${ }^{15}$ Put another way, there are more Muslims in China than there are in Saudi Arabia, and more in Nigeria than in Iraq, Syria, Jordan and Lebanon combined.

In the United States, Islam is the fastest growing religion. There are 5 million Muslims in the United States and currently represent the second largest religious group after Christians. Thus, more people in the United States are Muslim than Baptist or Jewish. ${ }^{15}$ The typical convert tends to be an urban African American male, although, among Caucasians and Latinos, more women convert than men, and they tend to be college educated. ${ }^{16}$ The racial/ethnic identity among Muslims living in America is as follows: 30\% black, 27\% Caucasian, 33\% Southeast Asian.

No papacy exists in Islam. There are scholars, acknowledged as experts in matters of law and ethics, whose opinions may be sought for contentious or contemporary issues, like the ones presented below. Scholars have divergent opinions on new issues and it is important to approach each Muslim patient or family as unique person and not a stone tablet with an indelible set of beliefs. Furthermore, each person's adherence to Islamic vs. cultural or personal beliefs will vary. This paper attempts to present commonly held beliefs among the two major Islamic sects, Shia and Sunni.

\section{CHILDREN IN ISLAM}

In Islam, children are a gift from God and described as the "joy of our eyes" (25:74). Children are to be respected in Islam as individuals with inherent rights (Table 2), applying equally to boys and girls. In fact, girls are a special joy in Islam. The Prophet Muhammad said, "What good offspring are girls!"17 He also urged parents to take special care of girls, providing them with "a proper upbringing, good education, and adequate material resources and recreational opportunities." 18

The role of parents is highly regarded in Islam too. Parents are more than legal guardians or caretakers. They are expected to treat their children gently, fairly, and well. When a child falls 
Table 1. Beliefs and Practices in Islam

\begin{tabular}{ll}
\hline Beliefs & \multicolumn{1}{c}{ Practices } \\
\hline Oneness of God & Daily prayers \\
Prophets and angels & Yearly fasting \\
Holy Scripture & Yearly 20\% tithe on savings \\
Resurrection and judgment & Pilgrimage once in a lifetime \\
Divine justice & \\
\hline
\end{tabular}

ill, parents feel a great sense of responsibility and failure to protect their child and ensure their health.

\section{DEATH IN ISLAM}

Wherever you are, death will find you out, even if you are in towers built up strong and high! (4:78)

\section{Physical aspect of death}

Both quality and sacredness of life are weighed in matters of life and death. Quality of life refers to the ability to live without meaningless suffering, as suffering has a redemptive aspect to it in Islam. Sanctity of life refers to the belief that all life is sacred because it originates with God and returns to God. When these two values conflict, the sanctity of life outweighs quality of life issues.

Muslims traditionally defined death as when the body grew cold after cessation of cardiac activity, although this was based on empirical observation and not prophetic command. In light of contemporary medical technology, most jurists recognize the clinical diagnosis of brain death as an acceptable reason for care to be deescalated. ${ }^{19}$ However, the Muslim laity still has difficulty with this concept and it is important for such a discussion to be broached with the help of community leaders, an observant Muslim physician, and/or local clerics. ${ }^{20}$

\section{Social aspects of death}

Most traditional societies and religions, from Buddhism $^{21}$ to Orthodox Judaism ${ }^{22}$ maintain a primacy on sanctity of life over quantity or quality. Many Muslims patients have an internalized understanding of these principles similar to those of traditional cultures and faiths and may be apprehensive about discussions regarding deesca- lation of care for a sick child or adult. Attending to an ill person and/or the funeral procession is highly recommended in Islam, and burial of the dead is a communal responsibility regardless of whether the person is a stranger or a local member of the community. Often, large groups of visitors will pay their respects to the deceased. Some cultures expect visible and dramatic signs of grief to demonstrate love and respect for the deceased. Some of these acts are practiced by Muslims but are not Islamically proscribed (see below).

\section{Religious aspects of death}

In Islam, life is a journey through the world, and death another journey through a spiritual world. The earth is described as a resting place for the purpose of worshipping God and doing good deeds (2:20-21). Boys are considered adults after the age of 15 , girls from 9 years of age in matters of religious obligations, therefore, adult aspects of death are discussed in this paper. Adult Muslims (discussed below) should make a will and testament in front of witnesses (5:106). Ideally this would include advanced directives regarding organ donation, disposal of the body after death, and payment of debts. A parent may determine if their child's organs may be donated.

In the dying moments, a Muslim recites or listens to the recitation of certain key verses from the Muslim scriptures, the Quran. The Quran can

TAble 2. Rights of ChiLdREN IN Islam

\begin{tabular}{ll}
\hline Positive rights & Negative rights \\
\hline Food & No hard labor \\
Shelter & No physical abuse \\
Medical care & No mental abuse \\
Education & No sexual abuse \\
Religious instruction & No forced marriage \\
Love and affection & \\
Dignified name & \\
Good spouse & \\
\hline
\end{tabular}


be read in any language in which the patient is familiar. The patient should be turned toward Mecca, or, to the East if the direction is not known. If that is not practical, the head can be turned to the patient's right. Rituals surrounding the time of death are summarized in Table 3. Autopsy is only allowed for forensics purposes or for organ donation. ${ }^{23}$

\section{Metaphysical aspects of death}

It is God who creates you and takes your souls at death. (16:70)

Health and illness, life and death are active processes in Islam willed by God: "And when I am sick, then [God] restores me to health; And He it is who will cause me to die, then give me life (in purgatory and again on the Day of Judgment) . . ." (26:80-81) This belief does not negate the importance of good health care. The prophet Muhammad himself practiced medicine and encouraged people to seek cures to their illnesses. Natural causes of illness such as contagion, seizures, congenital defects, and environmental factors were acknowledged by the Prophet Muhammad. ${ }^{24}$

Muslims often express a strong reliance on God's will. For example, a person's speech will be peppered with the phrase, insha' Allah, "if God wills (it to be)." This phrase is not a mark of fatalism, although some Muslims are fatalistic. It is rather a sign of putting one's trust in God once every effort has been made to remedy a situation. The implication is that ultimately, everything is in God's hands, and no mortal knows what the fruit of their labor will be or when they will reap it. Physician insistence on a bad prognosis, lack of hope for recovery, or insistence on withdrawal of care is seen as a rebellion against the natural order of the Universe, against human compassion, and in violation of God's order and writ. Often it creates a defensive attitude on the part of families, or distrust of medical staff.

Death in Islam is an active process, a transition for the soul from the material world to a spiritual world of purgatory. The prophet Mohammad explained, "Death is when the spirit leaves the body," 25 ending the relationship the soul had with body. The relationship among the three is as follows: spirit (ruh) is like energy, which enters the light bulb of the body (jism). The light that is a product of its relationship is the soul (nafs). ${ }^{26}$ The soul is the essence of a person, and is inclusive of what Freud referred to as Superego (89:27), Ego (75:2), and Id (12:53). When the energy is cut off, the light dims and the bulb is no longer functional.

Brain death, technically, is not considered death as far as Islamic metaphysics is concerned. That is not to say that Islamic scholars have not recognized the clinical role of brain death. However, as concerns end-of-life rituals, a person is not considered to be dead until the body has become cold and rigor mortis sets in. In this sense, the family should be allowed to stay with the patient and continue with end-of-life rituals (to be discussed below) until cardiopulmonary arrest is complete and the signs of death have become apparent to the laity.

\section{The meaning of the death of a child}

As in other religions and cultures, parents desire and assume that their children will outlive them. Illness and death can be very distressing for Muslim parents. ${ }^{27-28}$ Muslims liberally use supplication and prayer to seek natural and supernatural intervention for illness, as both come from God. The Prophet Muhammad said in this regard, "Prayer cures illness and there is no doubt in that." 24 Among Muslim laity, talismans are often used for sick children (and adults) to protect against the "evil eye" of others-that is, jealousy or malice-which may have contributed to a physical malady. ${ }^{29}$ Talismans may include blue

Table 3. Summary of Death Rituals for Muslim Children and Adults

Making a will and testament (adults ${ }^{\mathrm{a}}$ )

Seeking forgiveness of others (adults)

Reciting key verses of the Quran (adults)

Reiterating key beliefs (adults)

Facing Mecca at the time of death or

head turned to right if not practical (children and adults)

Closing eyelids (children and adults)

Closing and/or binding jaw (children and adults)

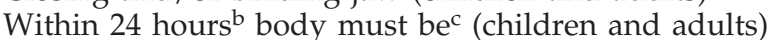

Ritually washed

Anointed

Shrouded

Prayed over

Buried

aAdulthood starts at 9 years of age for girls, 15 years of age for boys.

${ }^{\mathrm{b}}$ Burial may be delayed for forensic purposes.

'These five acts are to be performed on aborted and premature infants as well. 
glass or ceramic pendants resembling an eye, or lockets of various shapes containing small scrolls with verses of the Quran written on them. These objects should not be removed from the bed or body of an ill person unless medically necessary (i.e., magnetic resonance imagaing [MRI] scanner), and then only after discussion with the parents.

Among orthodox methods of spiritual healing is the "consumption" of verses of the Quran. Particular verses of the Quran are considered to have healing properties. ${ }^{30,31}$ Verses are written with a water-based saffron "ink" on a piece of paper. The paper is placed in a small bowl of water. When the saffron-inked verses dissolve into the water, the water is consumed. When done traditionally with saffron dissolved in warm water, the ink is safe to consume and does not pose a health risk.

In medieval Muslim societies, a special genre of literature was developed for consolation for the death of an infant or child. These treatises extolled and elaborated on key Islamic concepts in regard to the death of a child designed to make the pain of a child's death more bearable. Three prominent themes in this genre are the virtue of patience, intercession, and substitution. ${ }^{32}$

The first theme is patience. Patience is a great virtue in Islam and Muslims are encouraged to bear tribulations with fortitude. God's grace, explained the Prophet Muhammad to his followers, comes most to the person who praises God in good times and bad, and shows patience when his child dies. ${ }^{33}$

The second theme is intercession. Intercession refers to the ability of a person to plead for additional mercy and succor from God when judging a person's deeds and determining if they should go to heaven or hell. Ordinarily, the prophet Mohammad, martyrs, and other holy personages have the right of intercession according to Islamic teachings. However, the Prophet Mohammad taught that a child who dies, male or female, born or still-born, will intercede on their parent's behalf. The child will be granted automatic entrance into heaven for having died in a state of innocence. However, they will refuse God's permission to enter heaven without having their parents with them. Then, the children will take their parents by the hand and walk them into heaven without standing for judgment. ${ }^{31}$ This sentiment is often conveyed to grieving parents to ease their anguish.
The third theme of the death literature is substitution. It is believed that in God's unfathomable wisdom, the death of a child may be so that another child may be given to the parents who will be more pious. It could be that God's grace caused one child to die early, so that the child will die sinless, go to heaven and be able to intercede for his parents as mentioned above. This is referred to in the verse, "So their Lord desired to give them in place [of the son who died] one better than him in purity and nearer to having compassion." (18:81) The family was given a daughter in place of a son who had died. ${ }^{14}$

\section{DEATH, GRIEVING AND BEREAVEMENT-ISLAMIC PROSCRIPTIONS AND A CASE STUDY}

Upon the death of the Prophet Muhammad, Imam Ali (his close companion and son-in-law) remarked, "If you had not ordered endurance and prevented us from bewailing, we would have produced a store of tears. Even then, the pain would not have subsided, and this grief would not have ended, and they would have been too little of our grief for you. But this (death) is a matter that cannot be reversed nor is it possible to repulse it." 34

Grief is defined for this article as a "complex set of cognitive, emotional, and social difficulties that follow the death of a loved one." 35 Bereavement is defined as "the entire experience of family members and friends in the anticipation, death, and subsequent adjustment to living following the death of a loved one," including grief and mourning. ${ }^{36}$ Mourning refers to the ritual acts associated with death.

The Prophet Muhammad was himself an orphan having lost both his parents in childhood. As an adult, he lost every single son and numerous daughters. One episode is recounted in which he was burying his son, Ibrahim, who died in infancy. The death of this infant son is used as a case history of grief and mourning in Islam. The Prophet's cousin and son-in-law, Ali, is the narrator of the events. The story is told in sections and commented on below.

In Islam the following refrain from the Quran is uttered as a consolation after giving the news of a loved one's death: "Surely we are from God and to Him we are returning." (2:156)

When Muhammad's son died, he held him one 
last time, pressing the body against his chest. His eyes filled with tears and he said, "O my son, I didn't own you. You belonged to God (and now you are returning to Him)." ${ }^{37}$

Parents should be allowed to hold their deceased child's body if they so wish. Time and opportunity should be given for the family to grieve and express sadness at the hospital.

After death is pronounced, the following five acts should be performed, ideally within 24 hours after death: washing, anointing, shrouding, praying, and burying of the corpse (except in cases where forensic autopsy is required by law). A same-sex member of the community ritually washes the body. Ali starts the narration by saying,

When Ibrahim, son of Muhammad, died, [Muhammad] asked me to give him the ritual washing of the corpse. ${ }^{38}$

Some Muslim communities in Europe and North America have their own cold rooms and other facilities in their mosque, or use those of a local funeral parlor through previous arrangements. In some cases, the spiritual care department of a hospital will have a list of designated people and sometimes allow the body to be washed in the area where autopsies are performed. The body is then anointed and shrouded in a simple white seamless shroud. Again, Ali says,

[Muhammad] then wrapped him in the burial shroud and anointed the body. ${ }^{39}$

The body is then taken to the cemetery where a prayer is said for the dead, after which the deceased is interned in the grave. Ali continues in recounting the event:

(When we) reached the al-Baqi cemetery we prayed for [Ibrahim], then I approached the grave. ${ }^{39}$

Pathologic bereavement and grief is a concept that exists in Western discussions but is not common to other cultures, including Islamic culture. Public displays of sadness indicate to the community the loss of a dear member. It cues others to look after and relieve the bereaved from basic duties for a while, such as cooking. ${ }^{39}$ Crying in Islam is a sign of a person who loves and shows kindness to others. The Prophet Muhammad said, "Crying indicates a subtle and (spiritually) refined heart. Crying is a mercy from God that $\mathrm{He}$ gives to whomever he pleases. He shows mercy to people who are merciful to others." 40

Bereavement is excessive but not pathologic when it entails wailing and moaning. Concluding the story of when the Prophet Muhammad's son Ibrahim died, Ali says,

I showed the body to him one last time. I saw that he had become ill with grief and was crying. The men started crying too and soon their sobbing was very loud-louder than that of the women present. But Muhammad rebuked them saying, 'Shed tears from your eyes and grieve in your heart (but don't wail and moan)' . . . 39

Slapping cheeks, scratching the face, and tearing at clothes were strongly discouraged by the Prophet Muhammad, ${ }^{41}$ even though they are practiced in some parts in the Muslim world.

Regarding grief, there is no duration or limit to the time in which a person is expected to recover from the loss of a loved one, especially when the death is sudden or violent. The caveat is that the grief should not prevent one from engaging in routine activities and relationships. Muhammad's grandson Hussein was martyred in $680 \mathrm{AD}$. Hussein's son witnessed this horrifying event as a young man. He wept and grieved for his father every day for 40 years, until he himself was martyred. ${ }^{38}$ Nevertheless, his son led a full life, teaching theology, ethics and spirituality, authoring a spiritual masterpiece of supplications, Sahifah alSajjadiyyah, and was active in his family life. ${ }^{42}$ When grief interferes with daily activities, a Muslim is counseled to seek solace in prayers, supplications, and reflection on the meaning of the Quran. If that is not helpful, counseling should be sought with a scholar, or professional counselor. There is no prohibition on medication for grief and depression when necessary.

The Islamic customs noted above should be performed for all Muslims, male and female, including still-born and viable and nonviable premature infants. Open-casket viewing, embalming, elaborate coffins, and cremation are contrary to Islamic custom. Various schools of thought in Islam may or may not observe a mourning period on the third, seventh, and fortieth days after death. Some Muslim groups such as Salafis and Wahhabis do not allow women to attend funeral 
ceremonies at the cemetery. ${ }^{23}$ According to Shiite accounts, the Prophet Mohammad allowed it. He even allowed women to lead an all-woman congregation for a funeral prayer when his daughter Zaynab died, and when his contemporary Uthman ibn 'Affan's wife died. ${ }^{43}$ Shiites allow women to participate fully in the spectrum of bereavement rituals. As noted above, women were present at the cemetery and were more composed than the men were during the burial of Ibrahim.

\section{WITHHOLDING AND WITHDRAWING CARE}

In Islam, parents have an obligation to seek treatment for their children when the child is ill. If a child has an illness with a poor chance of cure and the side effects of treatment are painful and harmful for the body, the family can opt for palliative care. ${ }^{44}$ However, once care is started, if withholding care would lead to the child's death, it is considered to be a form of passive euthanasia. Neither passive nor active euthanasia is allowed in Islam. ${ }^{48}$ The two ultimate causes of death are cessation of cardiorespiratory activity or brain death. Withdrawing care is permissible in two circumstances. The first is when a diagnosis of brain death has been made. The second is when the current treatment, be it curative or palliative, is no longer curing or palliating suffering but merely prolonging a natural and inevitable death. ${ }^{45}$

\section{ORGAN DONATION}

Organ donation is permissible in Islam and has been encouraged by religious scholars of both the Shia and Sunni sects. ${ }^{20,23}$ There are a number of reasons why a Muslim family may not wish to donate organs. First, many families are unaware of organ donation, what it entails, and the legal rulings behind it. Many Muslim countries do not have organ transplantation programs. Of those countries that do have programs, most use living unrelated donors rather than living-related or cadaveric donors. ${ }^{20}$ Because of the traditional emphasis on burial within 24 hours, the family may believe that organ donation will unnecessarily delay burial. Muslim law normally prohibits the disfigurement of the dead. Therefore, the removal of organs may be seen as a violation of this precept.
During cases of acute death, caregivers usually have not established a sufficient relationship with the family to comfortably wade through cultural and social barriers to approach the subject of organ donation in a sensitive and effective manner. Hospitals with significant Muslim minority populations should consider maintaining relationships with local community leaders and educating them on the issue of organ donation so that they can be called upon to discuss the issue with families in an appropriate manner.

\section{DISCUSSING END-OF-LIFE CARE}

There comes a time when medical care for the critically ill patient becomes physiologically futile. At that point, the care team is not preserving life but preventing death. As with the role of Islamic culture on health care decision-making, there is very little evidence as to Muslim feelings on palliative care or de-escalation of care. Many Muslims come from countries where only tertiary health care needs are addressed and then primarily out-of-pocket to great expense. Furthermore, expertise and equipment may be in short supply. Physicians are expected by family members to lie to the patient about a grave prognosis in order to spare the patient grief in their final days. When encountering the healthcare systems of developed countries, these Muslims assume that "everything" will be done because there is often charity care, Medicaid, Medicare, or private insurance.

Palliative care, and especially de-escalation of care, is seen as "giving up" or shirking one's duty to heal. Furthermore, as with indigenous minority groups, immigrant Muslims may feel that inferior care is being given because of the patient's religion or ethnicity or level of insurance (selfpay, public aid, etc.), or that the physician is lying to the family, exaggerating a poor prognosis to end care sooner and make way for other patients.

Neither most Muslims-nor other non-Western people-accept the concept of physiologic futility. ${ }^{46}$ A discussion on futility may give an impression of medical abandonment, or be seen as an affront on God's will to determine the time of a person's death. Many Muslim ethicists acknowledge a point in the care of an ill person where life cannot be preserved and death is only being delayed. Unfortunately, this has not filtered down to the laity. Withdrawal of care has been 
cautiously accepted by some scholars in situations where a cure is considered unlikely and palliative treatment causes as much or more suffering than the illness itself. ${ }^{20}$

Suffering is considered a part of life, and forbearance of hardship is greatly rewarded in Islam. In particular, forbearance of an illness leads to expiation of sins in Islam. However, the Prophet Muhammad urged people to do what was more bearable for them personally. His wife recounts, "Whenever he ordered the Muslims to do something, he used to order them deeds which were easy for them to do." 47 These situations are best approached gingerly, with the help of a community leader, Muslim pastor or Imam, or physician on staff who shares the same religion as the family in order to lend a note of (religious) legitimacy to the concerns of the staff. ${ }^{48}$ The issue of futility, medical or nonmedical, is not widely recognized by jurisprudents at this time.

\section{CULTURAL ISSUES}

It is important for health care providers to have a general understanding of the principles of Islam and Islamic practices as a foundation for understanding commonly held beliefs and actions among Muslims. Health care providers should be aware of personal cultural beliefs and consider how this influences their interactions with patients from differing ethno-cultural groups. ${ }^{49}$

Practices that do not threaten biomedical goals and hospital policies should be tolerated, even encouraged. This is especially important when it comes to end-of-life issues, even more so with the death of a child, which is not only a personal tragedy but a societal one as well. Practices that may threaten biomedical goals or hospital policies should be engaged in a productive and nonthreatening manner. This will often require consultation with a health care worker who is a practicing coreligionist. Such a liaison can act as a transcultural interpreter between both the medical-laity gap as well as the conceptual gap between different religions and cultures.

\section{CONCLUSION}

Death is common to all people and varying cultures have their own way of understanding life, death, and the state after death. Cultures have ritualized expressions of grief and understandings of bereavement. ${ }^{48}$ Islam as a comprehensive system of spirituality and law engenders its own culture, which diverges with secular, Western values in key areas. ${ }^{50}$ This article discussed the most commonly held views on death, dieing, grief and bereavement based on "orthodox" sources, such as the Muslim scripture, the Quran, historical accounts of the life of the Prophet Mohammad, and rulings of contemporary scholars.

Customs before, during, and after death were discussed in detail in this paper. In particular, the death of a child may have one of three meanings: a test of patience for parents, a divine desire of a more pious child to be born in place of the current child, or, as an act of mercy to parents and the child with a guarantee of entry into Heaven for all three without standing for judgment.

The Islamic prescriptions for expression of grief (i.e. bereavement) include holding the deceased child, crying for them, and acknowledging that they were a gift from God that God has reclaimed. Weeping, wailing, and self-flagellation are not encouraged but tolerated. There is no concept of pathologic bereavement or grief in Islam as long as the person can engage in daily tasks of living. Those who cannot are encouraged to seek solace in religious teachings and seek appropriate counseling and medication when necessary.

Muslims, like followers of other religions, have a syncretic approach to religion that includes personal beliefs, pre-Islamic indigenous cultural practices and influences from non-Islamic, nonindigenous practices. Some non-Islamic practices among Muslims may actually contradict Islamic recommendations but be entrenched and culturally validated nonetheless. Every Muslim family should be approached individually and not as a tablet containing a "checklist" of cultural practices or beliefs.

\section{REFERENCES AND RESOURCES ON ISLAM}

For a brief introduction to Islam: 〈www.beliefnet.com/index/index_40118.html〉.

For further readings about Islam and the Quran: 〈www.al-islam.org〉. Resources on Islamic Ethics: 〈www.imamiamedics.org/〉; www.bbc. co.uk/religion/religions/islam/islamethics/; www.islamiclearning.org/Bioethics.htm

For speakers and educational seminars on healthcare needs of Muslims: 〈www.imamiamedics.org / $\rangle$ and $\langle$ www.ing.org $\rangle$. 


\section{REFERENCES}

1. Shakir MH (trans): The Quran, 2nd ed. Elmhurst, NY: Tahrik-e Tarsil-e Quran, 1985.

2. Hoyert DL, Mathews TJ, Menacker F, Strobino DM, Guyer B: Annual summary of vital statistrics: 2004. Pediatrics 2006;117:168-183.

3. Angus DC, Barnato AE, Linde-Zwirble WT, Weissfeld LA, Watson RS, Rickert T, Rubenfeld GD; Robert Wood Johnson Foundation ICU End-Of-Life Peer Group: Use of intensive care at the end of life in the United States: An epidemiologic study. Crit Care Med 2004;32:638-643

4. Lundqvist A, Nilstun T, Dykes AK: Neonatal end-oflife care in Sweden: the views of Muslim women. I Perinat Neonatal Nurs 2003;17:77-86.

5. DelVecchio Good MJ, Good BJ: Ritual, the state, and the transformation of emotional discourse in Iranian society. Cult Med Psychiatry 1988;12:43-63.

6. Suhail K, Akram S: Correlates of death anxiety in Pakistan. Death Stud 2002;26:39-50.

7. Elbedour S, Baker A, Shalhoub-Kevorkian N, Irwin M, Belmaker RH: Psychological responses in family members after the Hebron massacre. Depress Anxiety 1999;9:27-31.

8. State of the World's Children, 2004. UNICEF: New York, 2004. 〈www.unicef.org/media/media_15444. html $\rangle$ (Last accessed October 22, 2006).

9. McGreal C: The death and disorientation of the children of Gaza: In their homes, in the street, in UN-run schools, Palestinian youth are not safe from Israeli bullets. Guardian (London) September 17, 2004:Education Section.

10. Roberts L, Lafta R, Garfield R, Khudhairi J, Burnham G: Mortality before and after the 2003 invasion of Iraq: cluster sample survey. Lancet. 2004;364:1857-1864.

11. Ibrahim MM, Omar HM, Persson LA, Wall S: Child mortality in a collapsing African society. Bull World Health Organ 1996;74:547-552.

12. El-Sadig M, Norman JN, Lloyd OL, Romilly P, Bener A: Road traffic accidents in the United Arab Emirates: Trends of morbidity and mortality during 1977-1998. Accid Anal Prev 2002;34:465-476.

13. Board on Health Sciences Policy, Institute of Medicine. Patterns of childhood death in America. In: Field MJ, Behrman RE (eds): When Children Die: Improving Palliative and End-of-Life Care for Children and Their Families. Washington, D.C.: National Academies Press, 2003, pp. 41-71.

14. Shields MK Behrman RE. Children of immigrant families: Analysis and recommendations. Future Child 2004;14:4-15.

15. Islam: A Primer. Beliefnet.com. 〈www.beliefnet.com/ story/88/story_8830_1.html (Last accessed September 18, 2006).

16. Sanchez S, Galvan J: The changing face of Islam in America. Islamic Horizons 2002(July/August):22.

17. Hilli J: Uddatul $D a^{\prime} i$. hadith no. 219, Qom: Ansarian Publication, 1999.

18. al-Haithami A: Majma' al-Zawa'id wa manba' al-fawa'id, Vol. 7. Beirut: 1982, p. 158.
19. Aksoy S: A critical approach to the current understanding of Islamic scholars on using cadaver organs without prior permission. Bioethics 2001;15:461-472.

20. Raza M, Hedayat KM: Some sociocultural aspects of cadaver organ donation: Recent rulings from the Scholars of Iran. Transplant Proc 2004;36:2888-2890.

21. Perrett RW: Buddhism, euthanasia and the sanctity of life. J Med Ethics 1996;22:309-313.

22. Jakobovits Y, Tendler MD, Rosner F: Sanctity of life. Tradition 1994;28:131-133.

23. Gatrad AR: Muslim customs surrounding death, bereavement, postmortem examinations, and organ transplants. BMJ 1994;309:521-523.

24. Newman, AJ, ed; Batool Ispahany (trans.): Islamic Medical Wisdom: the Tibb al-A'imma. London: Muhammadi Trust, 1991.

25. Majlisi MB: Book 1: The wisdom of death and its reality, hadith no. 4. Bihar al-Anwar. Beirut: Mu'assasah al-Wafa'; 1984;6:117.

26. Al-Ghazali AH: The Marvels of the Heart: Al-Ghazali's Science of the Spirit, Abu Hamid Al-Ghazali. Kentucky: Fons Vitae, 2004.

27. Jacob SR, Scandrett-Hibdon S: Mothers grieving the death of a child. Case reports of maternal grief. Nurse Pract 1994;19:60-65.

28. Woolley MM: The death of a child-The parent's perspective and advice. J Pediatr Surg. 1997;32:73-74.

29. Segal S, Fletcher M, Meekison WG: Survey of bereaved parents. CMAJ 1986;134:38-42.

30. Hoffer C: Religious healing methods among Muslims in the Netherlands. ISM Newsletter 2000;6:8.

31. Saduq M: Thawab-al-Amal Wa Kitab-ul-Amal. Jame' al-Hadith, CD-ROM, Version 2.5. Qom: Noorsoft, 2004.

32. Akil M: Prophetic Healing: Philadelphia: Pearl Publication, 1993.

33. Gil'adi A: Children of Islam: Concepts of Childhood in Medieval Muslim Society. New York: St. Martin's Press, 1992.

34. Majlisi MB: Book 17: Ajr al-Masa'ib, hadith no.4. Bihar al-Anwar Beirut: Mu'assasah al-Wafa'; 1984;79:115.

35. Sharif al-Radhi M: Nahjul balagha: sermons, letters, and sayings of Imam Ali. Sermon no. 233, Qum: Ansariyan Publications; 1989. 〈www.al-islam.org/nahjul/233.htm〉 (Last accessed September 18, 2006).

36. Christ GH, Bonanno G, Malkinson R, Rubin S: Bereavement experiences after the death of a child. In: Field MJ, Behrman RE (eds): When Children Die: Improving Palliative and End-of-Life Care for Children and their Families. Washington, D.C.: National Academy Press, 2003, p. 555.

37. Christ GH, Bonanno G, Malkinson R, Rubin S: Bereavement experiences after the death of a child. In: Field MJ, Behrman RE (eds): When Children Die: Improving Palliative and End-of-Life Care for Children and their Families. Washington, D.C.: National Academy Press, 2003, p. 554.

38. Shahid al-Thani, Za-D: Musakkin al-Fu'ad, 1st ed. Qum: Intisharaat Kitabkhaneh Basirati, 1987.

39. Tabarsi HT. Book 74: Bab al-Buka' 'ala al-Mayyit wa al-Musibah wa Istihbabihi 'ind Ziyadah al-Huzn, ha- 
dith no.2464. Mustadrak al-Wasa'il wa-mustanbat almasa'il Beirut: Al-Mu'assasah 1987;2:460.

40. Majlisi MB. Book 16: Al-Ta'ziyyah wa al-Matam wa Adabuha wa Ahkamuha, hadith no. 19. Bihar al-anwar Beirut: Mu'assasah al-Wafa' 1984;79:82.

41. Tabarsi HT. Book 74: Bab al-Buka' 'ala al-Mayyit wa al-Musibah wa Istihbabihi 'ind Ziyadah al-Huzn, hadith no.2465. Mustadrak al-Wasa'il wa-mustanbat almasa'il Beirut: Al-Mu'assasah 1987;2:460.

42. Mufid M: Session 12, hadith no. 4. In: Jaffer MAMM (trans): Al Amaali: The Dictations of Sheikh al-Mufid. Middlesex: World Federation of Khoja Ithna-Asheri Muslim Communities; 1998, PP. 110-111.

43. ibn al-Husein A: The Psalms of Islam (As-Sahifa al-Kamilah al-Sajjadiyya). Qom: Ansariyan Publishers, 1983 $\langle$ www.al-islam.org/sahifa/〉 (Last accessed September 18, 2006).

44. 'Amuli M. Book 39: chapter on permissibility of women participating in the prayer of the dead. hadiths nos. 3228, 3229. Wasa'il al-Shi'ah, Qom: Mu'assasah Aal Al-Bayt; 1989;3:138.

45. Hedayat KM, Pirzadeh R: Issues in Islamic biomedical ethics: A primer for the pediatrician. Pediatrics 2001;108;965-971

46. Khomeini R: Rulings on the final moments of life. In: Rohani M, Noghani F (eds): Ahkam-e Pezeshki, Tehran, Iran: Teymurzadeh Cultural Publication Foundation; 1998:306. Rulings Nos. 1-3.

47. Nakata Y, Goto T, Morita S: Serving the emperor without asking: critical care ethics in Japan. I Med Philos 1998;23:601-615.

48. Bukhari M. Book 2: Book on Belief, hadith no.19. Khan MM, trans. The English translation of Sahih al Bukhari with the Arabic text. Alexandria, VA.: Al-Saadawi Publications, 1996. 〈www.usc.edu/dept/MSA/fundamentals/hadithsunnah/bukhari/ $\rangle$ (Last accessed September 18, 2006).

49. da Costa DE, Ghazal H, Al Khusaiby S: Do not resuscitate orders and ethical decisions in a neonatal intensive care unit in a Muslim community. Arch Dis Child Fetal Neonatal Ed 2002;86:F115-119.

50. Koenig BA, Davies E: Cultural dimensions of care at life's end for children and their famlies. In: Field MJ, Behrman RE (eds): When Children Die: Improving Palliative and End-of-Life Care for Children and their Families. Washington, D.C.: National Academy Press, 2003. $\langle$ www.nap.edu/catalog/10390.html $\rangle$ (Last accessed September 18, 2006).

51. Moaddel M, Azadarmaki T: World views of Islamic publics: The cases of Egypt, Iran, and Jordan. In: Inglehart R, Diez-Medrano J, Halman L, Luijk R (eds): Human Beliefs and Values. Mexico City; 2004. 〈www.worldvaluessurvey.org/Upload/5_Iran.pdf (Last accessed September 18, 2006).

Address reprint requests to: Kamyar Hedayat, M.D.

Sutton Children's Hospital-Pediatrics

1 St. Mary's Place

Hospitalist Group

Shreveport, LA 71101

E-mail: kamyar.hedayat@chrisushealth.org 